\title{
ENSO-Type Wind Stress Field Influence over Global Ocean Volume and Heat Transports
}

\author{
Luiz Paulo de Freitas Assad \\ Federal University of Rio de Janeiro/COPPE/LAMCE \\ Brazil
}

\section{Introduction}

Ocean-atmosphere interactions have a fundamentally important effect on the heat energy provided by the sun. Solar radiation that reaches Earth's surface generates heat gain in tropical ocean regions and heat loss in high latitudes. This energy is redistributed above the continents exclusively via the atmosphere, whereas energy redistribution above the oceans occurs through a cooperative relationship between the oceans and the atmosphere (Hastenrath, 1979). Knowledge of the relationships between oceanic and atmospheric processes and their variability are of great importance to Earth climate studies. Oceanic and atmospheric climate variability may be associated with interactive processes, such as the well-studied El Niño Southern Oscillation (ENSO). Although ENSO processes are centred in the Equatorial Pacific region, changes in tropical atmospheric convection could affect the atmospheric circulation of the entire planet. This perturbed atmospheric circulation, particularly the low-level wind stress field, could affect not only ocean transport but also the spatial and temporal distribution of certain dynamic and thermodynamic ocean properties, especially in the upper layers of the ocean (Colberg and Reason, 2004).

In some regions, such as the Antarctic Circumpolar Current (ACC) system, most of the variability in volume transport is associated with the barotropic field. High correlation values between the deep ocean pressure field and the wind stress field can be observed at the southern side of the Drake Passage (Whitworth \& Peterson, 1985). Interannual variability in ACC volume transport has also been associated with global climate variability phenomena such as ENSO. Lenn et al. (2007), analysing five years (1999-2004) of ADCP (High-resolution Acoustic Doppler-Current Profiler) datasets from the Drake Passage from three repeated cross channel tracks, found negative surface layer $(<250$ meters) volume transport anomalies during the period between 2002 and 2003, which were ENSO years. Even though this result is inconclusive, it suggests a weakening of the surface ACC flow in the Drake Passage associated with the 2002-2003 ENSO event.

The influences of global interannual variability are not only observed in large-scale ocean features. Lentini et al. (2001) studied sea surface temperature variability in the southwestern Atlantic region. The authors observed a southward and northward advection of cold and warm anomalies $\left( \pm 1^{\circ} \mathrm{C}\right)$ during and immediately after ENSO events and noted that the larger amplitudes of these anomalies were situated at the La Plata River and Patos Lagoon offshore regions. Assad et al. (2010) studied the influence of an ENSO type global wind stress field on the upper ocean temperature anomalies over the Brazil - Malvinas 
Confluence region and observed positive and negative temperature anomalies associated with upper layer volume transport changes in the Brazil Current. The authors also observed changes in the upper layer of ACC volume transport.

This work aims to identify and quantify the occurrence and influence of global ENSO-type wind stress forces on global ocean heat and volume transports and their interannual climate variability using an Ocean General Circulation Model (OGCM). This phenomenon could cause climate changes in the amount of heat storage in each ocean basin, which could induce climate variability in the nearby continental regions. This kind of information would be very useful to be applied in global climate models in order to better understand how heat energy would be distributed over the planet by the occurrence of an ENSO event.

The ocean model was forced with a three-year transient ENSO-type global wind stress field. The results show significant changes in the global ocean integrated kinetic energy field that represent a direct response to changes in the volume transports integrated for different density water levels around the world's ocean basins. Changes in the ocean volume transport around the world were observed not only in the upper density layers of the ocean but also, to a minor degree, in the deep and bottom density layers. These observed changes in ocean volume transports caused changes in the global water column integrated heat transport, which, in turn, caused significant changes in the global meridional overturning cell circulation along the perturbed wind experiment.

\section{Methodology}

This work applied an Ocean General Circulation Model (OGCM) as a tool for investigating the variability of ocean volume and heat transports in the world's oceans. The Modular Ocean Model 4.0 (Pacanowsky \& Griffies, 1999), developed by the Geophysical Fluid Dynamics Laboratory (GFDL, National Oceanic and Atmospheric Administration, Princeton, New Jersey, USA), was used for this study. This verical z-coordinate model has been largely adopted by the scientific community for global climatic research investigations. It is mathematically formulated with a Navier-Stokes set of equations under the Boussinesq and hydrostatic approximations. The system of continuous equations are basically completed by an equation of state of sea-water, the continuity equation for an incompressible fluid, and conservation equations for temperature and salinity.

The longitudinal resolution of the model was $1^{\circ}$ worldwide and the latitudinal resolution increased from $1^{\circ}$ to $1 / 3^{\circ}$ within the $10^{\circ} \mathrm{N}-10^{\circ} \mathrm{S}$ equatorial band. Fifty levels were implemented on the vertical axis. To achieve a higher resolution near the ocean surface, the first 22 levels were located in the top $220 \mathrm{~m}$ of the water column. The thickness of each level varied from $10 \mathrm{~m}$ to a maximum of $366.6 \mathrm{~m}$ near the sea bottom $(5500 \mathrm{~m})$. Regions shallower than $40 \mathrm{~m}$ were not considered. The grid constructed on this work uses the tripolar grid method by Murray (1996). It adopts normal spherical coordinates south of $65^{\circ} \mathrm{N}$ while North of this latitude two numerical poles situated on land regions of Asia and North America are used. This method minimizes problems related with the convergence of meridians over the ocean that happens mainly in North Pole.This grid followed the oceanic component of the GFDL climate model presented in the 4th IPCC Assessment of Global Climate Changes. Boundary conditions of the OGCM were established by fields of wind stress, sea surface temperature, sea surface salinity, sea surface heat fluxes, sea surface elevation, runoff and precipitation. The model used three-dimensional temperature, salinity and velocity as the initial conditions. All of boundary and initial conditions will be further detailed in the next section. 
Two experiments were conducted to estimate anomalous ocean volume and heat transports. The first sought to obtain the ocean climate transports and was used as a control parameter to determine ocean transport anomalies during ENSO conditions. The second experiment constituted a perturbed condition, where an ENSO-type wind stress field was imposed as a boundary condition. These anomalous boundary conditions were represented by monthly mean global wind stress fields generated by an AGCM experiment (Torres Jr., 2005). The AGCM was integrated for three years and used boundary conditions based on the 19821983 ENSO event.

The ocean volume and heat transport were estimated for selected zonal and meridional sections of the entire world ocean (Figure 1). The choice of these sections followed two basic criteria: the existence of estimates in the scientific literature and the dynamic relevance of the analysed region in the global ocean circulation. Ocean volume transports were estimated for three different density $(\sigma)$ levels in units of kg.m-3: upper $(\sigma<27.5)$, deep $(27.5<\sigma<27.8)$ and bottom $(\sigma>27.8)$. These three levels were chosen based on the study conducted by Schmitz (1996). The author used data sets from the World Ocean Circulation Experiment to study the global ocean circulation transports in these three different levels. In fact, the upper layer chosen for the current study is a compilation of surface and intermediate layers investigated by Schmitz (1996) as follows: Surface Layer Water, Upper Layer Water, SubAntarctic Mode Water (SAMW), upper SAMW, lower SAMW and total intermediate water (IW). The ocean heat transports were estimated for the whole water column in each monitored section.

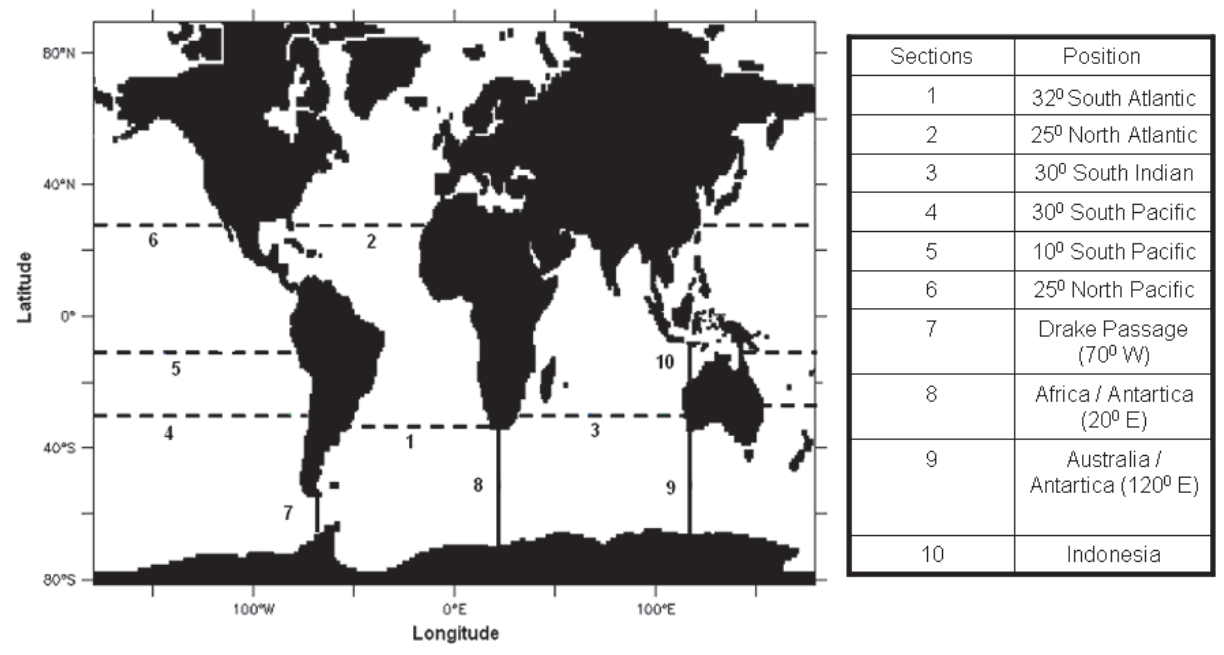

Fig. 1. Sections where volume and heat transports were estimated. Each section is identified by a number and a name.

The geometry of each monitored section together with the annual climatological mean space distributions of the analysed density levels are illustrated in Figure 2. The annual mean bottom layer density levels were not obtained in only two sections: Indonesia and $25^{\circ}$ North Pacific. It is also important to note the presence of known density distribution behaviours, as 
the strong eastward low level winds around the Antarctic continent generate ocean current via Ekman transport and induce the sloping of isopycnals observed in ACC meridional sections (Schmitz, 1996; Russel, 2006). In the other zonal sections the isopycnal lines are not as sloped as meridional sections reflecting more water column stratification, observed in these regions (Schmitz, 1996).
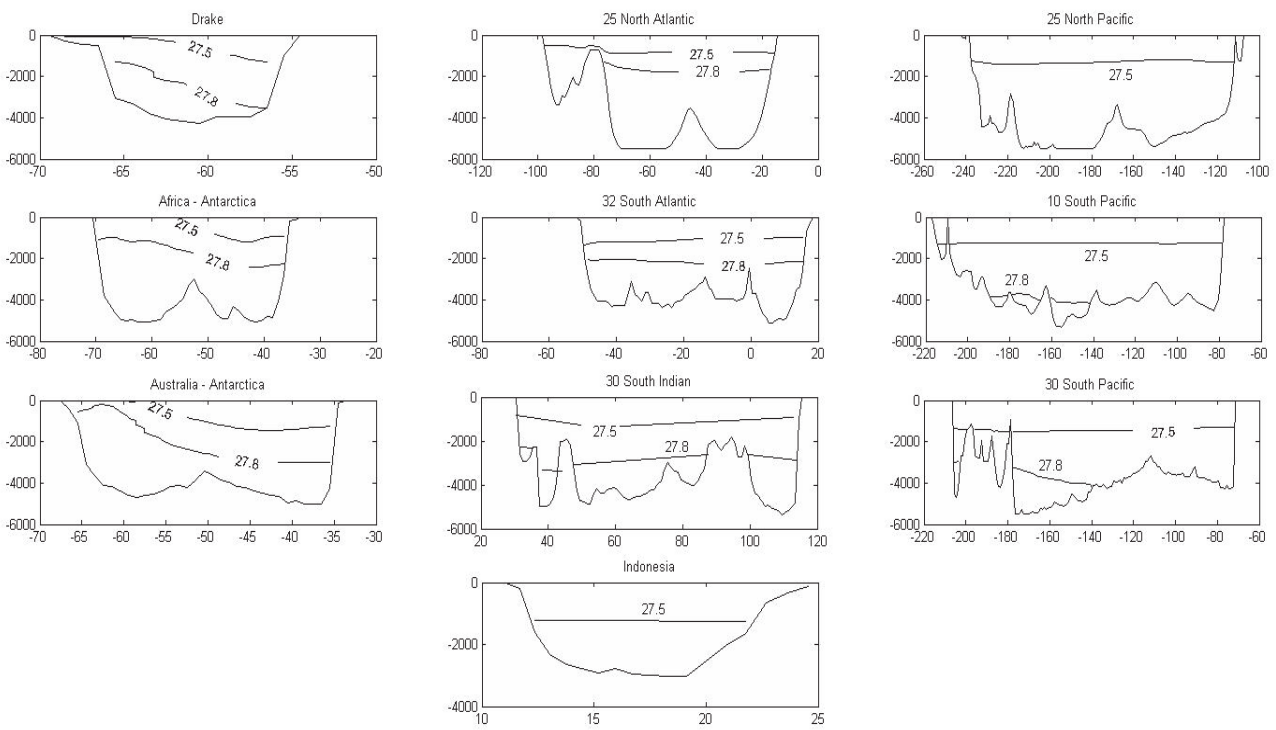

Fig. 2. Geometry of the monitored sections with 27.5 and 27.8 control experiment isopycnal lines (in units of $\mathrm{kg} \cdot \mathrm{m}^{-3}$ ) superimposed.

\subsection{Control experiment}

As previously described, this experiment mainly aims to estimate the climate behaviour of volume and heat global ocean transports. The three-dimensional temperature, salinity and velocity data sets from the Ocean Data Assimilation for Seasonal to Interannual Prediction experiment (ODASI) conducted by GFDL were used as the initial condition in the climate experiment (Sun et al., 2007). The month of January 1985 was chosen to be the initial condition for the climate experiment because it did not present strong climate variability phenomena such as El Niño.

The sea surface boundary conditions were taken from the climatological data set of the Ocean Model Intercomparison Project (OMIP). This version of the OMIP data set was produced by the ECMWF (European Centre for Medium-Range Weather Forecasts) under project ERA-15 (Röeske, 2001). The variables used for surface forcing were meridional and zonal wind stress components, net short- and long-wave radiation, sensible heat flux, specific humidity flux, frozen and liquid precipitation and river runoff. The boundary fields given above were cyclically imposed on the model until it reached an equilibrium state. The model was integrated for seven years with an external mode time step of $80 \mathrm{~s}$ and a baroclinic time-step of $4800 \mathrm{~s}$. Using 8 processors of an ALTIX 350 computer, the model was able to complete one simulated year in approximately 1.5 days, generating approximately 2 GB output per model year. 


\subsection{Perturbed experiment}

The main goal of this experiment was to identify interannual variability in the global ocean transports induced by a three-year transient wind stress field. The perturbed experiment used the September monthly mean dynamic and thermodynamic fields generated by the control experiment as initial conditions, but with only anomalous wind stress boundary conditions. These anomalous boundary conditions were determined by monthly mean global wind stress fields generated by an atmospheric general circulation model experiment (AGCM). The AGCM was integrated for three years, and it used Pacific Equatorial sea surface temperature boundary conditions based on the 1982-1983 ENSO event (Torres Junior, 2005; Assad et al., 2010). The ocean model was integrated for 36 months (three years) in this experiment. The annual mean values for volume and heat transports in each monitored section were then estimated and analysed.

\section{Results}

\subsection{Control experiment}

The integrated global ocean kinetic energy shows a well-defined cyclic behaviour starting at the second integration year (Fig. 3). The most energetic periods occur during austral winter and the less energetic periods occur during austral summer. This result indicates that the ocean kinetic energy annual cycle is dominated by the wind stress annual energy cycle (Oort et al., 1994).

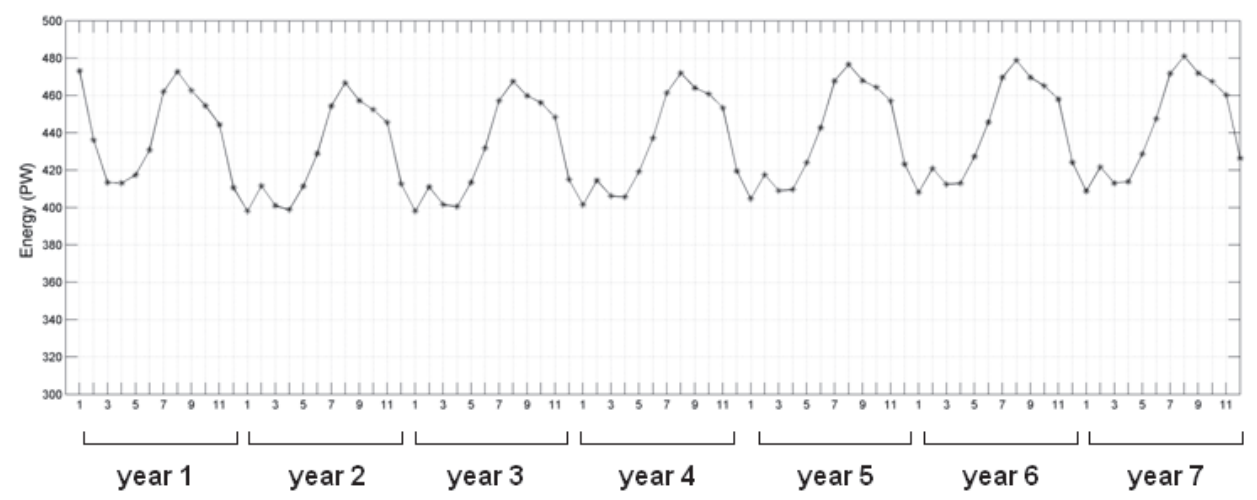

Fig. 3. Time series of the integrated ocean kinetic energy for the whole integration domain in $\mathrm{PW}\left(\mathrm{PW}=10^{15} \mathrm{~W}\right)$.

\subsubsection{Volume transport}

The obtained volume transports showed good agreement with the published values. The values obtained here also represent important aspects of wind-driven ocean climates and thermohaline circulation. Figure 4 shows the directions and intensities (units of Sv) of the annual mean ocean volume transports that were vertically integrated for the three different density levels for each monitored section. 


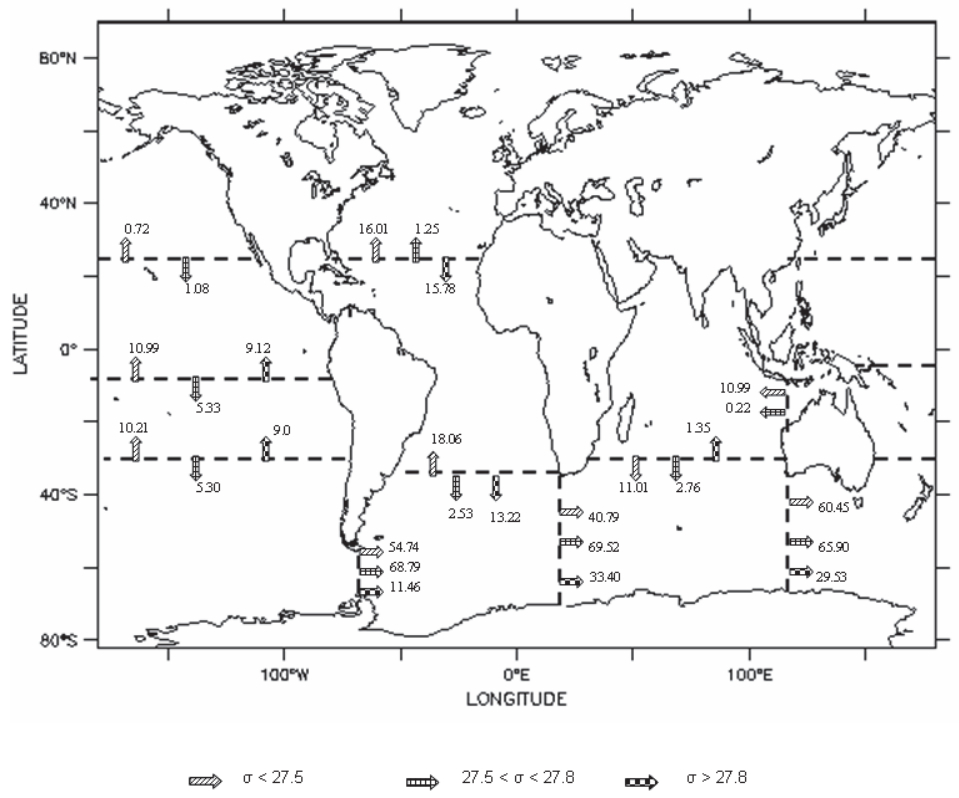

Fig. 4. Annual mean ocean volume transports for the defined density levels.

The analysis of this map revealed, for example, a strong eastward flow for the three monitored density levels associated with the ACC around the Antarctic continent. The obtained vertically integrated volume transport in this section is $134.99 \mathrm{~Sv}$. Ganachaud \& Wunsch (2000), using hydrographic data from the World Ocean Circulation Experiment (WOCE), estimated a value of $140 \mathrm{~Sv}( \pm 6)$ for a section situated near the Drake Passage. Stammer et al. (2003), using an OGCM constrained by WOCE project data, obtained a value of $134 \mathrm{~Sv}( \pm 7)$ for a Drake Passage section. The model was also able to reproduce the seasonal cycle of ACC volume transport, with higher values during austral winter months and lower values during austral summer months (Figure 5).

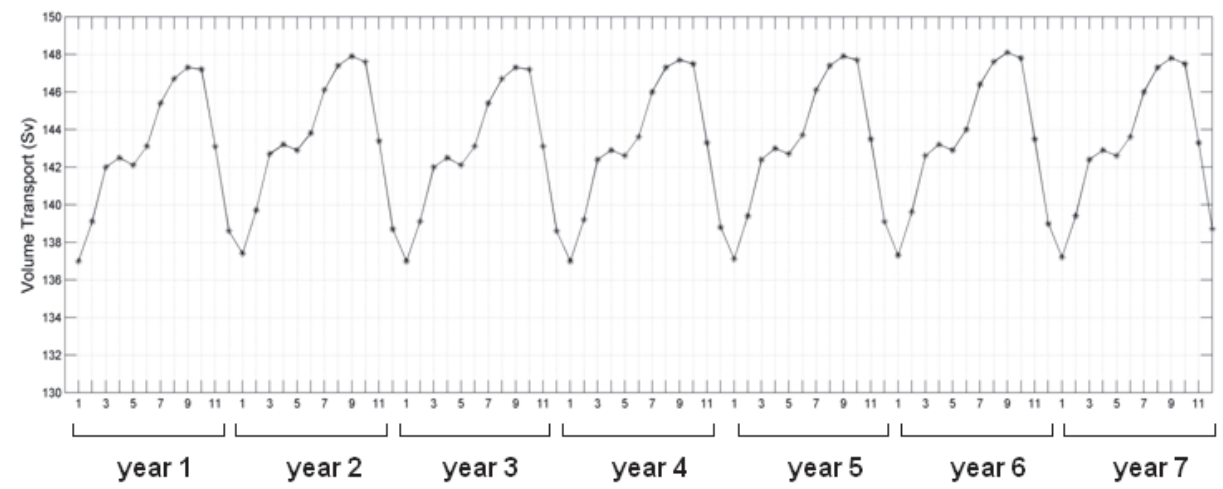

Fig. 5. Time series of zonal volume transport across the Drake Passage (Fig. 2; section 7) in Sv. 
For a South Atlantic zonal section situated near $25^{\circ}$ S, Ganachaud \& Wunsch (2000) estimated a value of $16 \mathrm{~Sv}( \pm 3)$ for an upper level layer northward transport with $\sigma<27.72$. The authors also estimated a resultant southward transport of $17 \mathrm{~Sv}$ for a South Atlantic zonal section situated near $25^{\circ} \mathrm{S}$ for a layer with $\sigma>27.72$. For the $32^{\circ}$ South Atlantic section monitored in the present study, a value of $18.06 \mathrm{~Sv}$ was obtained for the northward upper density level layer. For the bottom layer, a southward volume transport of $13.22 \mathrm{~Sv}$ was obtained.

The $25^{0}$ North Atlantic section revealed a $16.01 \mathrm{~Sv}$ northward volume transport for the upper layer. The resultant integrated volume transport of deep and bottom layers was in the southward direction, with an intensity of 14.53 Sv. Ganachaud \& Wunsch (2000) estimated a southward volume transport with an intensity of $17 \mathrm{~Sv}$ in a section situated near the $25^{\circ}$ North Atlantic section.

The westward volume transport of the Indonesian Throughflow was also observed for the upper and deep layers, and it showed a total transport of 11.21 Sv (Figure 2). Ganachaud \& Wunsch (2000) estimated a value of $16 \mathrm{~Sv}( \pm 5)$ for the total westward transport. Stammer et al. (2003) obtained a value of $11.5 \mathrm{~Sv}( \pm 5)$ for this section.

In the $30^{\circ} \mathrm{S}$ and $10^{\circ} \mathrm{S}$ South Pacific sections, a northward flow in the upper and bottom layers was observed, whereas a southward flow was observed in the intermediate layer. The volume transport of the upper layer values in these sections were $10.21 \mathrm{~Sv}$ and $10.99 \mathrm{~Sv}$, respectively. For a Pacific zonal section situated near $20^{\circ}$ S, Ganachaud \& Wunsch (2000) estimated a northward volume transport of $19 \mathrm{~Sv}( \pm 5)$ in an upper layer with $\sigma<27.2$ (Stammer et al., 2003)

\subsubsection{Heat transport}

For the purposes of this study, the term "heat transport" refers specifically to heat advection (advective heat transport) associated with the mean ocean flow. The vertically integrated mean (from the sea surface to sea bottom) heat transport and respective variance across each monitored section are plotted in Figure 6. The Atlantic and Pacific zonal sections showed northward heat transports, whereas the Indian Ocean zonal section presented a southward heat transport (Stammer et al., 2003; Ganachaud \& Wunsch, 2000). It is important to observe the significant variance values mainly for the $10^{\circ}$ South Pacific section. The South Atlantic section exhibited a northward heat transport of $0.60 \pm 0.02 \mathrm{PW}\left(1 \mathrm{PW}=10^{15}\right.$ Watts), reinforcing the peculiar behaviour of the South Atlantic basin as an exporter of heat to the North Atlantic. Using hydrographic data, Rintoul (1991) estimated the average value of 0.25 PW $( \pm 0.12)$ for a zonal section in the South Atlantic at $32^{\circ}$ S. Hastenrath (1980, apud Rintoul, 1991) estimated a value of $1.15 \mathrm{PW}$ for the meridional heat transport in the South Atlantic basin.

The most intense heat transports are associated with the ACC zonal flux through its meridional sections (Fig. 1; sections 7, 8, and 9). The time series plot for the vertically integrated heat transport perpendicular to each monitored section also reveals a well defined annual cyclic behaviour (not shown). For the Drake Passage section (Fig. 1; section 7 ), the maximum values are found in austral summer and the minimum values in austral winter. The magnitude of this transport ranges from 1.48 to $1.58 \mathrm{PW}$ with a mean value of 1.52 PW. These values agree with the previous estimate of 1.3 PW (Ganachaud \& Wunsch 2000) and 1.14 PW ( \pm 0.06$)$ obtained by Stammer et al. (2003). A less intense heat transport was observed in the Africa-Antarctica section (0.98 PW), which could be explained by the 
influence of the westward Agulhas Current flow, which is present in the upper layers of this section.

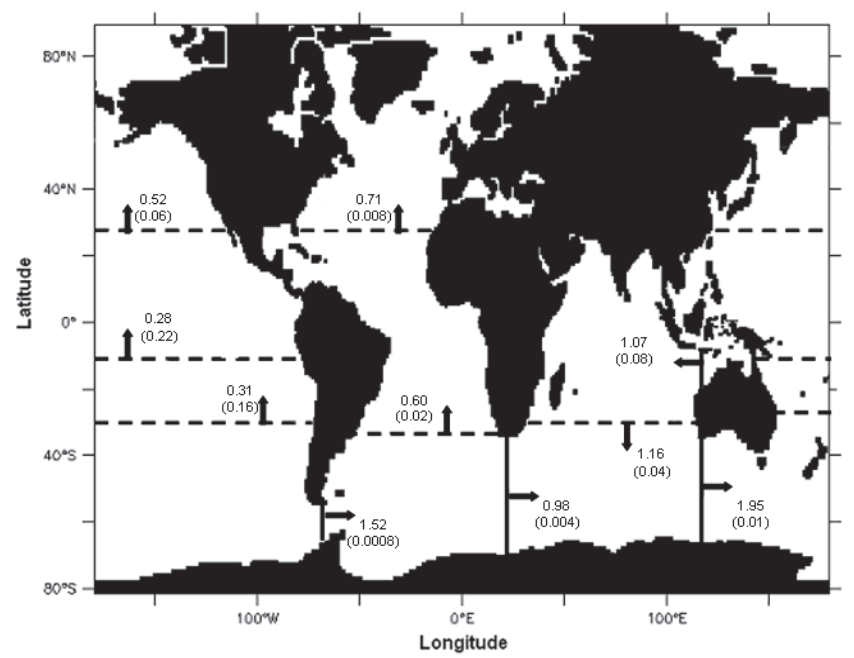

Fig. 6. Vertically integrated annual mean heat transport (direction and intensity) and associated variance (in $\mathrm{PW}^{2}$ ) in each monitored section for the entire water column.

Figure 7 presents the latitudinal distribution of the whole water column integrated meridional heat transport over the world's ocean basins. This figure reveals the presence of an intense northward heat transport between the equator and $40^{\circ} \mathrm{N}$ and a southward heat transport between the equator and $40^{\circ} \mathrm{S}$, which indicates that the conducted experiment was able to reproduce the so-called conveyor belt circulation. Using a geostrophic method on data obtained during the WOCE project, Ganachaud \& Wunsch (2000) estimated a mean value of $-0.6 \mathrm{PW}( \pm 0.3)$ for the global meridional heat transport across $30^{\circ} \mathrm{S}$ and $2.2 \mathrm{PW}( \pm$ $0.6)$ across $12^{\circ} \mathrm{N}$. At the same latitudes, we found values of $-0.2 \mathrm{PW}( \pm 0.01)$ and 1.75 (with variance of $\left.0.03 \mathrm{PW}^{2}\right)$, respectively.

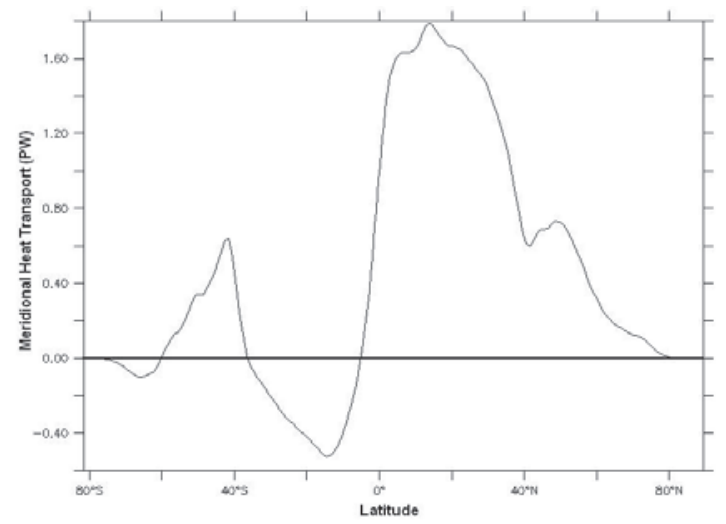

Fig. 7. Global integrated annual mean meridional heat transport (in PW) for the control experiment. 


\subsection{ENSO perturbation experiment}

The global ocean integrated kinetic energy anomaly time series during the perturbed experiment is shown in Figure 8. This figure reveals the transient behaviour of this experiment, where the global ocean kinetic energy curve follows the global integrated work performed by the wind curve with a small time lag. The second year presented the most energetic months, and the global ocean kinetic energy maximum peak occurred in the 23rd month of integration. The global ocean work performed by the wind stress field over the sea surface had an energy peak in the 21st month. This result suggests a time lag of approximately two months between the peaks in global wind energy that led to the global ocean kinetic energy. It is important to emphasise that ocean dynamic and thermodynamic anomalies were observed before and after the ocean kinetic energy peak that occurred during the second integration year.

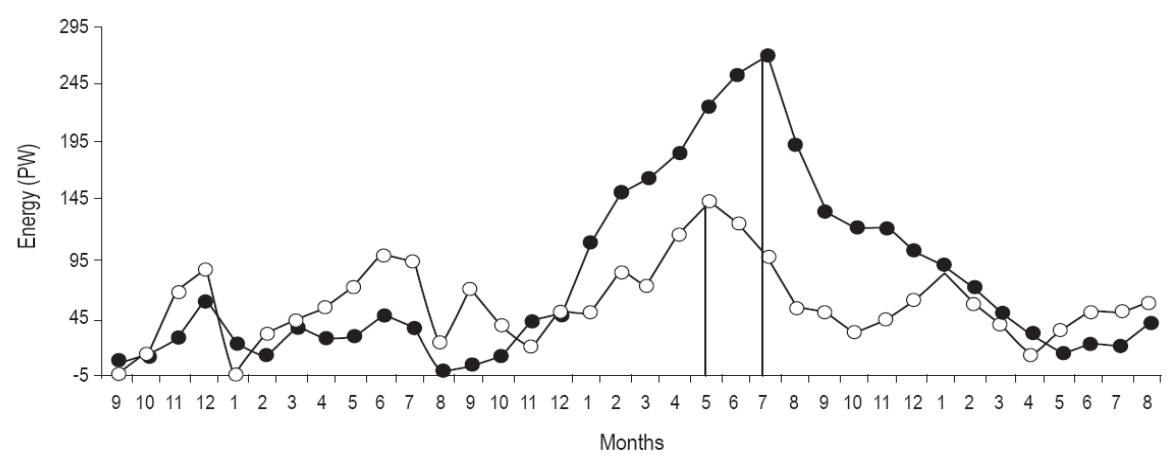

Fig. 8. Kinetic energy time series plot (filled circles for the ocean kinetic energy and empty circles for the global wind energy over the sea surface). The values of the work performed by the wind were multiplied by a factor of $10^{3}$.

The annual mean global wind stress field for the control experiment and the anomaly wind stress field for each perturbed simulated year are presented in Figure 9. This figure reveals the presence of a significant anomalous wind stress circulation in all the world's ocean basins over the course of the simulated three year experiment. Specifically, there were obvious differences in the westward wind stress vectors around the Antarctic continent. These features reveal a decrease in the eastward low level wind circulation in this region throughout the perturbed experiment. It is also important to note the increased presence of anomalous wind stress difference vectors in the low and mid latitude ocean regions during the second integration year. These regions exhibited lower values in the first and third years, indicating less intense changes in the wind stress field during these years. The North Atlantic basin exhibited a decrease in the low level atmospheric subtropical gyre for the first year and an increase for the second perturbed year. The South Atlantic basin also exhibited a small increase of the low level atmospheric subtropical gyre during the second integration year. The Equatorial Pacific region exhibited the most intense differences in wind stress vectors fields during the second integration year, and the southeast trade winds system seemed to increase over the Pacific Ocean region this same year. 

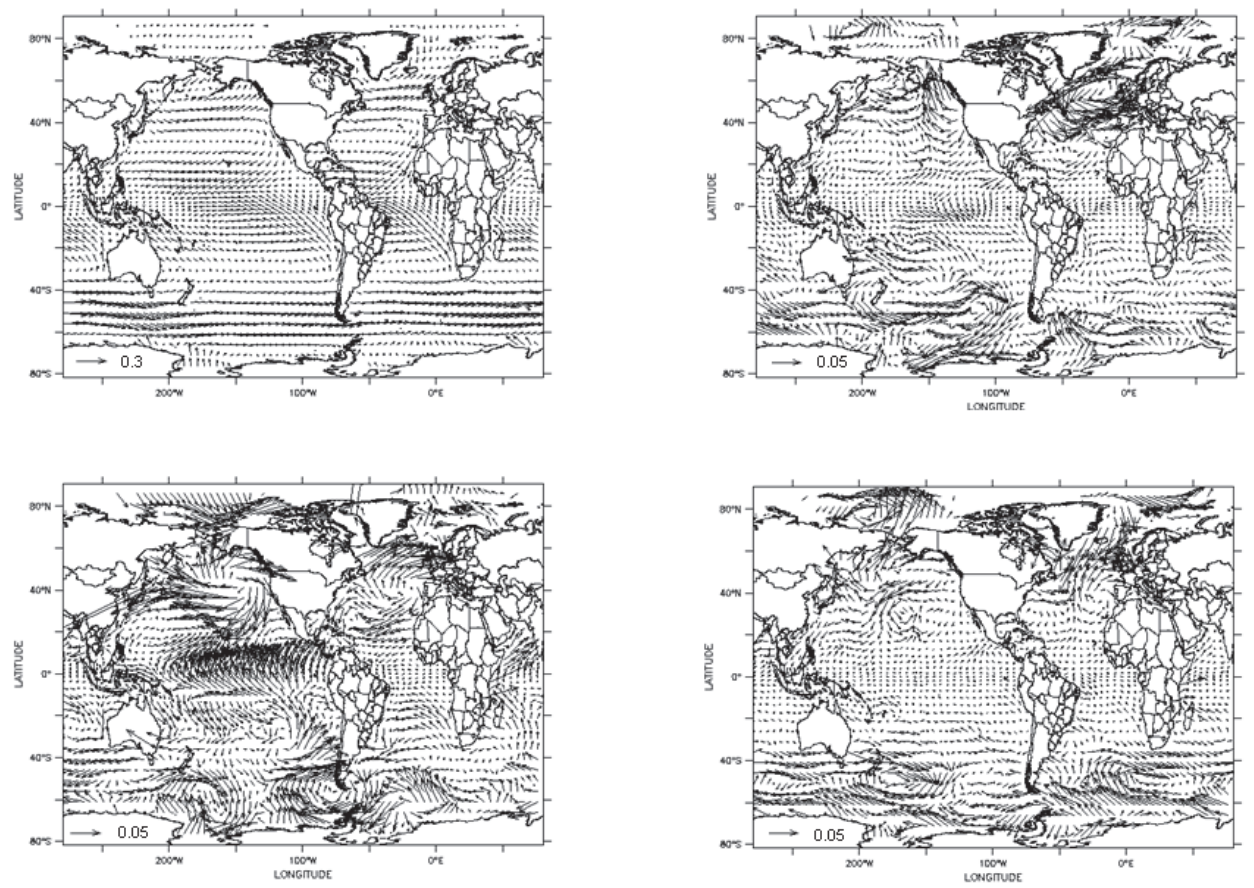

Fig. 9. Annual mean wind stress climatological vector field (upper left). Annual mean anomaly wind stress field for years 1 (upper right), 2 (lower left) and 3 (lower right). All values are in $\mathrm{Pa}$.

\subsubsection{Volume Transport}

The annual mean volume transports integrated for the three selected levels in each monitored section for the first integration year are represented in Figure 10. This figure reveals an intensification of the northward upper layer volume transport for both Atlantic zonal sections ( $32^{\circ}$ South Atlantic and $25^{\circ}$ North Atlantic). For the bottom layer, $32^{\circ}$ South Atlantic exhibited an increase of southward volume transport, and the $25^{\circ}$ North Atlantic section exhibited a small decrease of the southward volume transport. The ACC meridional sections of the Drake Passage and Australia-Antarctica exhibited an increase of the eastward upper layer volume transport, while the Africa-Antarctica section exhibited a small decrease. The deep layer volume transport decreased for all ACC sections. The bottom layer showed an intensification of the eastward volume transport for the two ACC zonal sections bordering the South Atlantic basin. The Indonesian Throughflow section exhibited a small decrease of the upper layer volume transport for this year. The $30^{\circ}$ South Indian section exhibited an increase in the upper and bottom layer volume transports, while a decrease in the deep layer was observed. The $30^{\circ}$ and $10^{\circ}$ South Pacific sections exhibited a decrease in the northward upper layer volume transport, while an increase was observed in the $25^{\circ}$ North Atlantic upper layer volume transport. The bottom layer volume transport of the Pacific sections decreased in a volume transport decrease relative to control experiment values. 


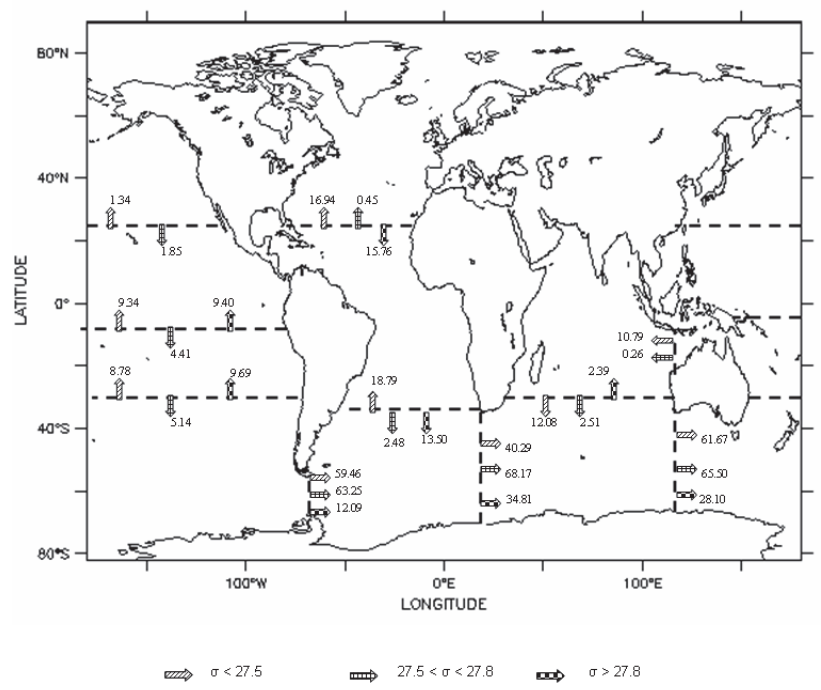

Fig. 10. Annual mean ocean volume transports for the selected levels in each monitored section for each defined density level in the first perturbed integration year.

The annual mean volume transports integrated for the three selected levels in each monitored section for the second integration year are represented in Figure 11. As explained in Figure 8, this period was the most energetic year. As in the first integration year, positive and negative anomalies were observed throughout all the world's ocean basins. The $32^{0}$ South Atlantic section volume transports decreased in all the analysed density layers. The $25^{0}$ North Atlantic section exhibited intensification of the northward upper layer transport and in southward bottom layer transport. The deep layer volume transport decreased and changed direction toward the south during the second integration year. Almost all the ACC meridional sections showed a decrease in volume transport during the second integration year. The intermediate density level volume transport in the Drake Passage section was the only exception, which increased by $1.65 \mathrm{~Sv}$ during this year. The $30^{\circ}$ South Pacific and $25^{0}$ North Pacific zonal sections exhibited an intensification of the upper level northward volume transport, while the $10^{\circ}$ South Pacific section exhibited a decrease in the upper layer northward volume transport. The deep layer southward volume transport increased in all three Pacific zonal sections. The bottom layer transports decreased. The Indonesian Through flow eastward volume transport decreased during the second integration year. The $30^{\circ}$ South Indian upper and bottom layer volume transports exhibited a southward and northward intensification, respectively.

The annual mean volume transports integrated for the three selected levels in each monitored section for the third integration was characterised by a decrease of the global integrated ocean kinetic energy in relation to the second integration year (Figure 8). The $32^{0}$ South Atlantic section exhibited the most intense northward upper layer volume transport value. The southward bottom layer transport for this section also intensified slightly, while the southward deep layer transport exhibited a small decrease. The $25^{0}$ North Atlantic section exhibited an intensification of the northward upper layer volume transport, while a decrease was observed in the deep layer southward transport. For the deep layer transport, 


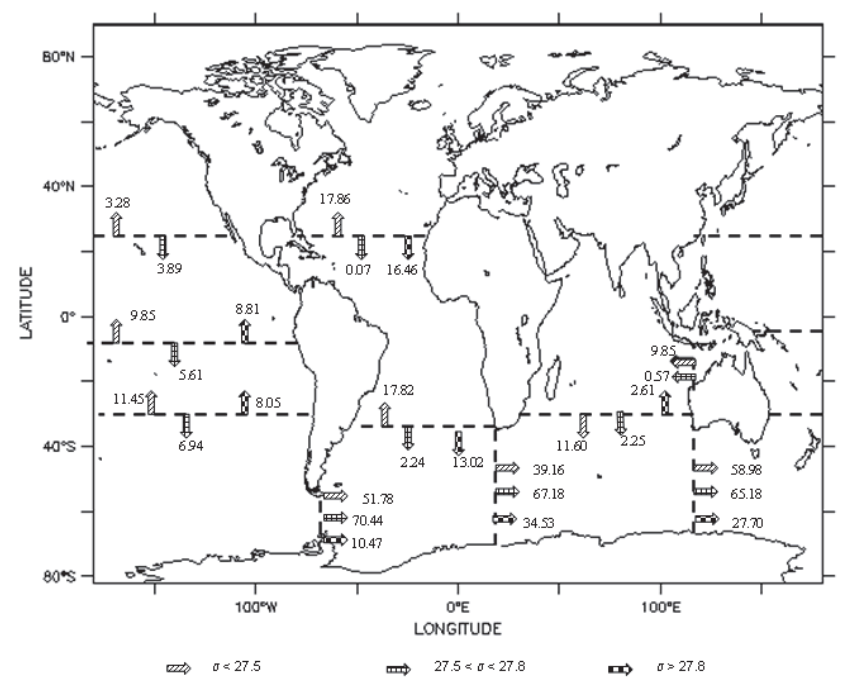

Fig. 11. Annual mean ocean volume transports for the selected levels in each monitored section for each defined density level in the second perturbed integration year.

an intensification of the southward volume transport in relation to the value observed in the second integration year is apparent. All the ACC upper layer volume transport values exhibited a decrease in their intensity compared with the control experiment values. The upper and deep layer volume transports of the Pacific sections intensified. The bottom layer transports decreased in all monitored Pacific sections. The Indonesian Throughflow westward volume transport exhibited the lowest values of the three integration perturbed years. The $30^{\circ}$ South Indian volume transports decreased in all the monitored density layers.

\subsubsection{Heat transport}

The global meridional heat transport integrated for the entire water column showed significant changes for all simulated perturbed years. Figure 12 presents the integrated heat transport across each monitored section for the first perturbed year. The $32^{\circ}$ South Atlantic section demonstrated a small increase of the northward heat transport $(0.64 \mathrm{PW})$ compared with the control experiment value $(0.60 \mathrm{PW})$. The $25^{\circ}$ North Atlantic section also showed an increase in the northward heat transport, at $1.10 \mathrm{PW}$. The three ACC sections exhibited an intensification of the eastward heat transport. The increase in the northward meridional heat transport for the Atlantic sections could be related to the upper layer volume transport intensification of both sections as observed in Figure 10 The Indonesian Through flow section exhibited a decrease in the westward heat transport $(0.82 \mathrm{PW})$ compared to that of the control experiment (1.07 PW). In the Pacific basin, a decrease in the northward heat transports of the $30^{\circ}$ South Pacific and $10^{\circ}$ South Pacific sections was observed, whereas there was an increase in the northward heat transport across the $25^{\circ}$ North Pacific section. These results can be explained by the data illustrated in Figure 10, which reveals an increase in the upper layer volume transport of the two South Pacific sections, and a decrease in volume transport in the upper layer at $25^{\circ}$ North Pacific. The $30^{\circ}$ South Indian section 
exhibited an increase in the southward heat transport. A value of 1.29 PW was observed for this section.

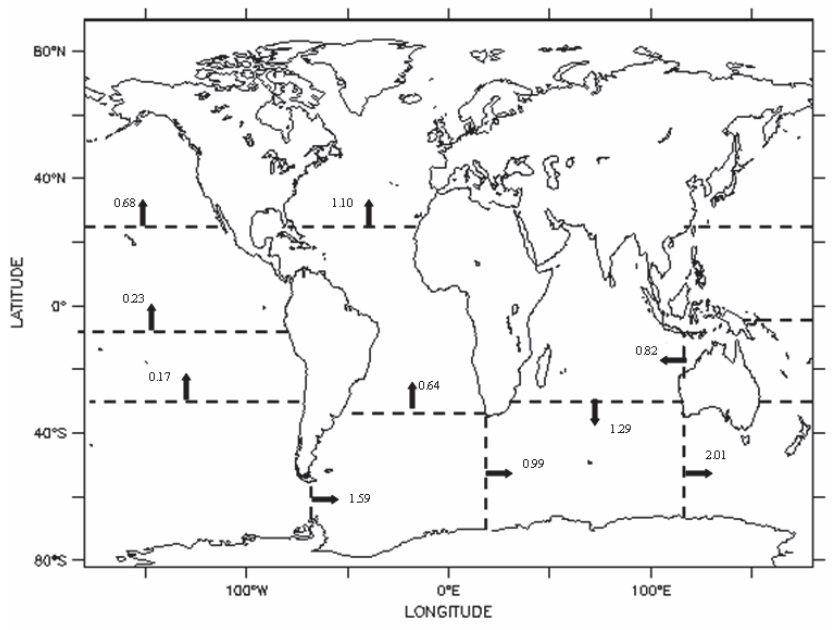

Fig. 12. Annual mean ocean heat transports integrated for the whole water column in each monitored section in the first perturbed integration year.

Figure 13 presents differences between the integrated meridional heat transport of the perturbed (for the first year) and control climate experiments. An intensification of the global meridional overturning cell was observed during this year. An increase of the southward heat transport was observed between $40^{\circ} \mathrm{S}$ to $10^{\circ} \mathrm{S}$, and an increase of the northward heat transport was seen between $7^{\circ} \mathrm{S}$ to $28^{\circ} \mathrm{S}$

The southern oceans show a decrease in the northward heat transport across the South Pacific section, while an increase in the southward heat transport across the $30^{\circ}$ South Indian section is observed. These processes could explain the increase of the southward integrated meridional heat transport observed in Figure 14.

Figure 14 shows the whole water column integrated heat transport across each monitored section for the second perturbed integration year. The $32^{\circ}$ South Atlantic section exhibited a small decrease in the northward meridional heat transport, while the $25^{0}$ North Atlantic section exhibited a strong increase of this transport with a value of $1.18 \mathrm{PW}$. This result seems to be related to the increase in northward volume transport in the upper layer during this year. Also in this year, all the ACC meridional sections presented a decrease of the eastward heat transport associated with the observed decrease in eastward volume transport, with the exception of the Drake Passage deep layer transport, which showed an increase relative to that of the control experiment. As with the first perturbed year, the Indonesian Through flow exhibited a decrease again in eastward heat transport. The southward heat transport across the $30^{\circ}$ South Indian section was lower than that observed in the first perturbed integration year, but this value was still greater than observed for the control experiment. The $30^{\circ}$ South Pacific and $25^{\circ}$ North Pacific sections exhibited an increase in the northward heat transport in comparison with the first perturbed year value. 


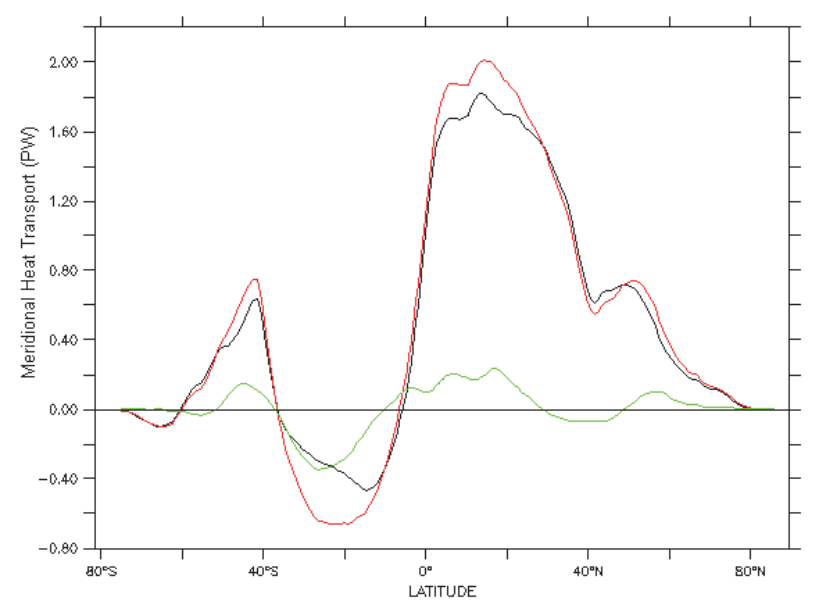

Fig. 13. Global integrated annual mean meridional heat transport (in PW) for the climate experiment (black) and the first year perturbed experiment (red). The difference between the perturbed and climate experiments is also shown (green).

The $10^{\circ}$ South Pacific section exhibited an inversion of the resultant integrated heat transport from the north to south direction. A value of $0.22 \mathrm{PW}$ was obtained in this section. It is important to note that the second integration year is also the period of greater global wind energy, especially in the Pacific low latitude regions. This fact could explain the inversion of heat transport, which, for this year, also exhibited a strong variance of $1.85 \mathrm{PW}^{2}$, which is even greater than the average value.

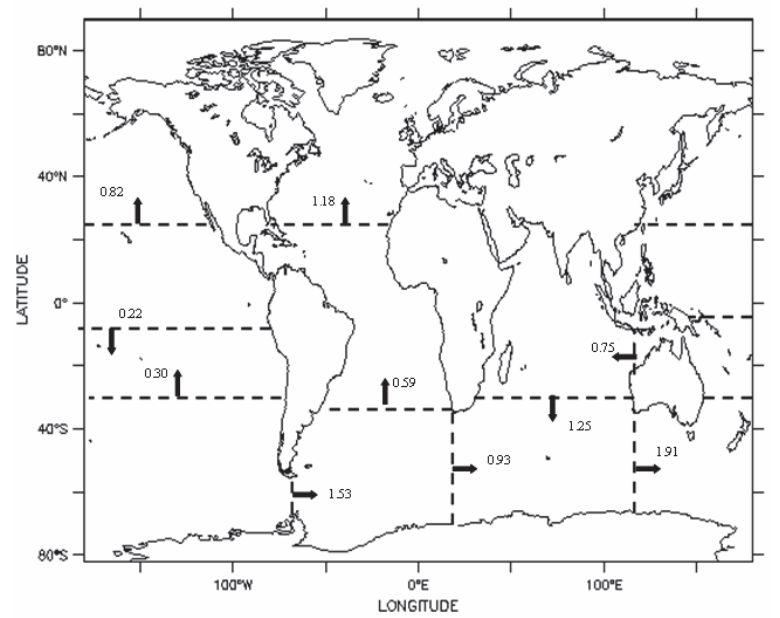

Fig. 14. Annual mean ocean heat transports integrated for the whole water column in each monitored section in the second perturbed integration year.

Figure 15 presents the global integrated meridional heat transport for the second integration year, the control experiment curve and the difference curve between the second perturbed 
year and the control experiment. This figure reveals a significant increase in the heat transport conveyor belt circulation. An increase of approximately $0.6 \mathrm{PW}$ is observed for the northward heat transport at approximately $20^{\circ} \mathrm{N}$. An increase of approximately $0.4 \mathrm{PW}$ is also observed in the southward heat transport observed between the equator and $20^{\circ} \mathrm{S}$. The intensification of this southward heat transport is directly related to the increase in the $30^{0}$ South Indian heat transport and the reversion to the south of the $10^{0}$ South Pacific heat transport.

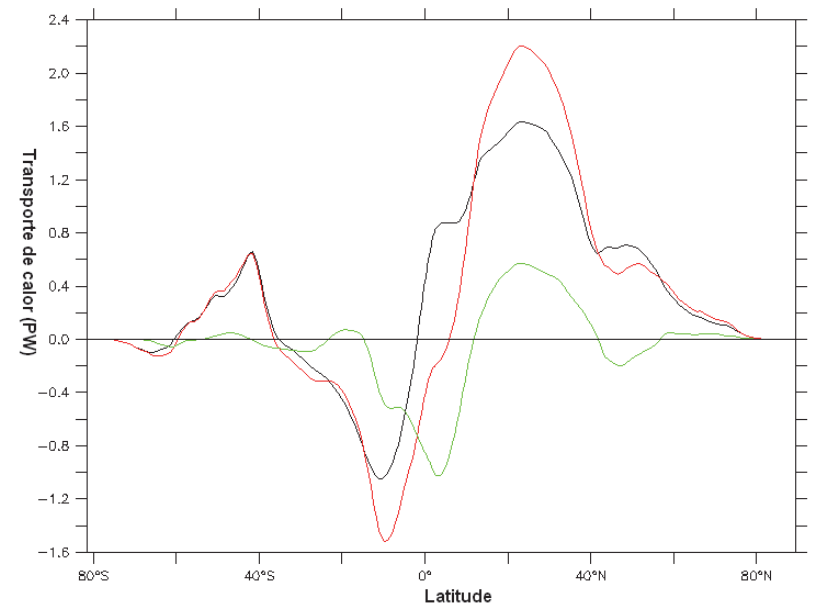

Fig. 15. Global integrated annual mean meridional heat transport (in PW) for the climate experiment (black) and the second year perturbed experiment (red). The difference between the perturbed and climate experiments is also shown (green).

In the third perturbed integration year, the global wind stress field returned slowly to the conditions observed in the first perturbed year. The heat transports obtained in some sections were still greater than the values observed in the control experiment. The whole water column integrated northward heat transport observed in the $25^{\circ}$ North Atlantic and $32^{\circ}$ South Atlantic sections were 1.07 PW and 0.66 PW, respectively, for the third year. The Africa-Antarctica, Australia-Antarctica and Drake Passage sections, presented greater eastward heat transport values than the control experiment values. The $30^{\circ}$ South Indian southward heat transport remains smaller than the value obtained for the control experiment. The Indonesian Throughflow section presented the smallest westward heat transport value obtained for the whole perturbed experiment with a value of $0.65 \mathrm{PW}$. This result could be associated with the decrease in the upper layer volume transport across this section during this year. The $30^{\circ}$ South Pacific section exhibited an increase in northward heat transport. The $10^{\circ}$ South Pacific heat transport reverted to the north, as with its control experiment condition, and it strongly increased in intensity to a value of $0.84 \mathrm{PW}$. The $25^{0}$ North Pacific section exhibited a decrease in the northward heat transport related to the second integration year, but it was still greater than observed for the control experiment.

The higher meridional integrated heat transport values were observed during the third integration year in the latitudinal band between the equator and approximately $10^{\circ} \mathrm{N}$. In this region, a maximum value of $2.6 \mathrm{PW}$ for a northward heat transport was observed. This result could be explained by the strong intensification of the northward heat transport at $30^{\circ}$ 
and $10^{\circ}$ in the South Pacific. Northward heat transport also intensified across the $32^{\circ}$ South Atlantic section, which would contribute to the intensification of the northward integrated heat transport. In the high northern latitudes, there was no apparent difference in heat transport between the perturbed and control experiments.

\section{Discussion}

The main goal of the control experiment was to represent the important climatological, thermodynamic and dynamic features of global ocean circulation. As demonstrated in section 3, the integrated global ocean kinetic energy shows a well-defined cyclic behaviour starting at the second integration year (Figure 3). The ocean volume and heat transports for the seventh integration year over the monitored sections were also consistent with previous estimates in nearby regions. Even though the analysis of some prognostic model variables, such as the ocean transport field and even the integrated ocean kinetic energy, indicate a cyclic climatic behaviour, it is possible to identify a small time-growth tendency of the kinetic energy curve. This trend is linearly estimated as $1.82 \times 10^{11}$ Watts/day, which represents only $0.0003 \%$ of the difference between the maximum and minimum global values of the ocean kinetic energy. This result could be attributed to the difference between the OMIP (Ocean Modelling Intercomparison Project) wind stress field used in this work and the ODASI (Ocean Data Assimilation for Seasonal-to-Interannual Prediction) wind stress forcing field that was used to produce the initial conditions (temperature, salinity and ocean velocity fields). According to Wunsch (1998), the largest contribution to the global wind stress field comes from zonal wind stress component, which represents most part of the global work performed by the wind. The main regions of zonal wind energy input are the Southern Ocean, the Kuroshio region, and the Gulf Stream/North Atlantic Current regions.

Figure 16 shows that the zonal wind component in OMIP is more intense than in ODASI at most latitudes, especially for the high latitude bands of both hemispheres, where most of the energetic wind stress field is found. The difference between OMIP and ODASI wind stress globally averaged in space and time is $6.22 \times 10^{11}$ Watts/day, which is of the same order as the global kinetic energy growth rate $\left(1.82 \times 10^{11}\right.$ Watts / day $)$.

An important point to be discussed is the methodology used to generate the anomalous ENSO-type global wind stress field used in the perturbed experiment. As cited previously, the perturbed wind stress field was generated by an AGCM (Section 2.2). The boundary condition used for this AGCM was a synthetic sea surface temperature (SST) field that was produced based on the 1982-1983 ENSO event (Torres Jr., 2005). The synthetic SST anomaly field was generated by the combination of two Gaussian analytical functions representing the time and space domains (Figure 17).

Figure 20 reveals that the Gaussian function weight peak is centred in the 16th month, when the most intense SST anomaly values occurred, which are centred between the equator and $15^{\circ} \mathrm{S}$ and between $165^{\circ} \mathrm{W}$ and $90^{\circ} \mathrm{W}$. An Equatorial Pacific anomaly SST field produced a global wind stress energy peak only in the 21st month and a global ocean kinetic energy peak only in 23rd integration month (Figure 8). There was a delay of seven months between the Equatorial Pacific SST peak and the global ocean kinetic energy peak.

As was observed in the volume and heat transports obtained for the perturbed experiment, changes in the global wind stress field caused by the occurrence of an important global climate variability process such as ENSO could affect the whole world ocean circulation. 


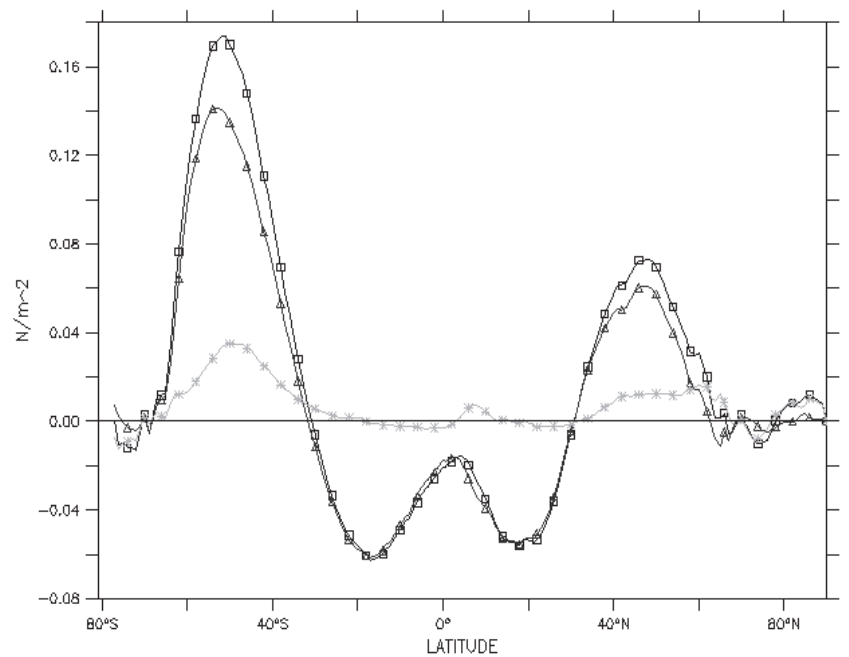

Fig. 16. Zonal distribution of the annually averaged zonal wind stress field from the OMIP $(\square)$ and ODASI $(\Delta)$ datasets and the difference between them $\left(^{*}\right)$.
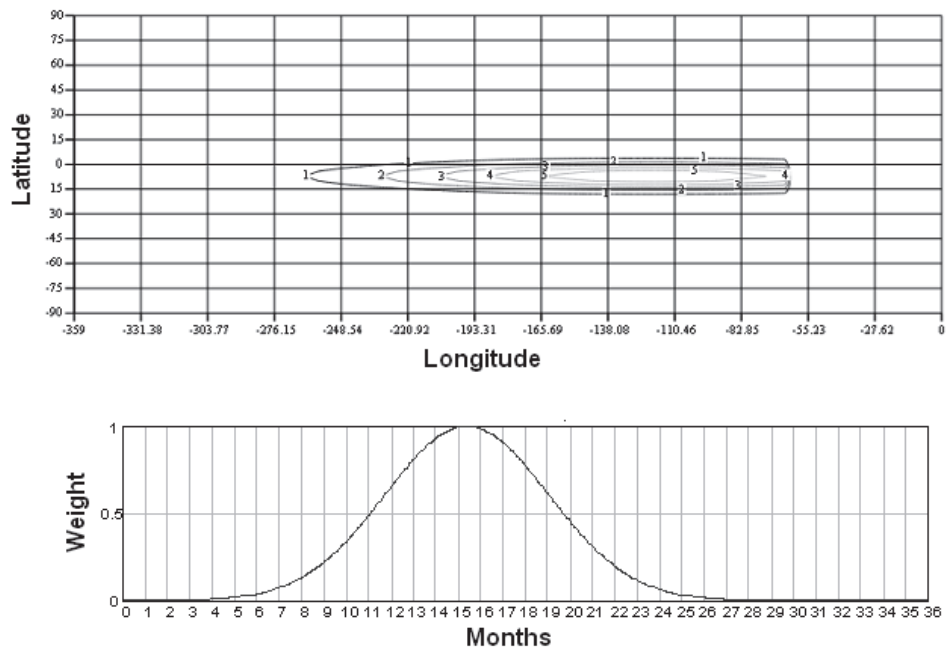

Fig. 17. Space (above) and time (below) Gaussian distributions used to generate the synthetic SST anomaly fields used as the boundary condition of the AGCM. 
Figure 18 shows the time series plot of the total heat content in the South Atlantic, North Atlantic, South Pacific and North Pacific basins during the control and perturbed experiments. The black curve represents the cyclic values obtained for the climate experiment for each of these ocean basins. This figure shows for the control experiment a cyclic behaviour with an increase of heat amount during the summer months and a decrease during the winter months as a direct result of the solar radiation cycle, which ensures a gain of heat by the ocean during the summer months and a loss of heat during the winter months. The perturbed experiment revealed for the monitored ocean basins a tendency for heat loss in the northern ocean basins and a tendency for heat gain in the southern ocean basins during the three years of the simulation. These tendencies continued even after the ocean kinetic energy peak that occurred in the 23rd integration month.
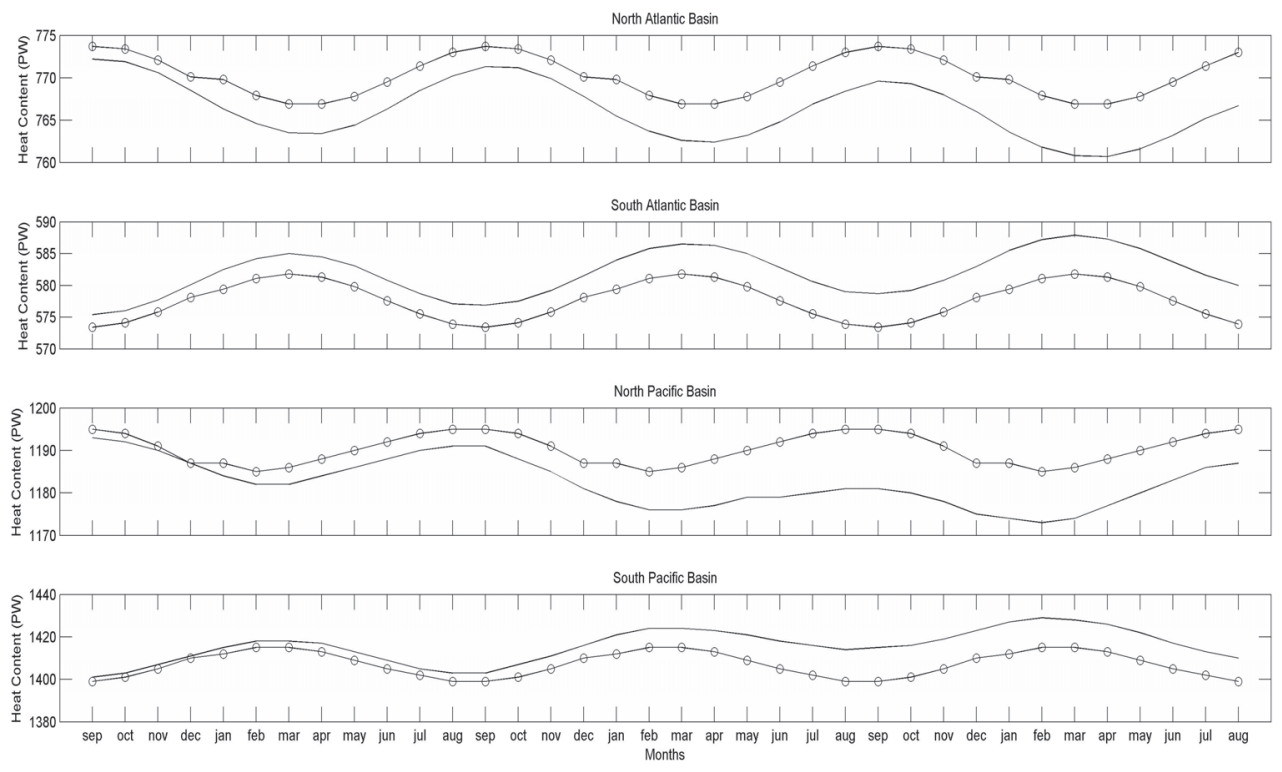

Fig. 18. Time series plot of the total heat content (PW) in the South Atlantic, North Atlantic, North Pacific and South Pacific basins during the perturbed experiment for the control (o) and perturbed experiments.

It is important to note that the only change in boundary conditions for the model in the perturbed experiment was the wind stress field. As described previously, this field was used as an ENSO-type global wind stress field imposed during the three years of the model integration. The sea surface radiation balance is also important to explain the space and time distribution of heat over the ocean basins, but changes in its field typical for ENSO events 


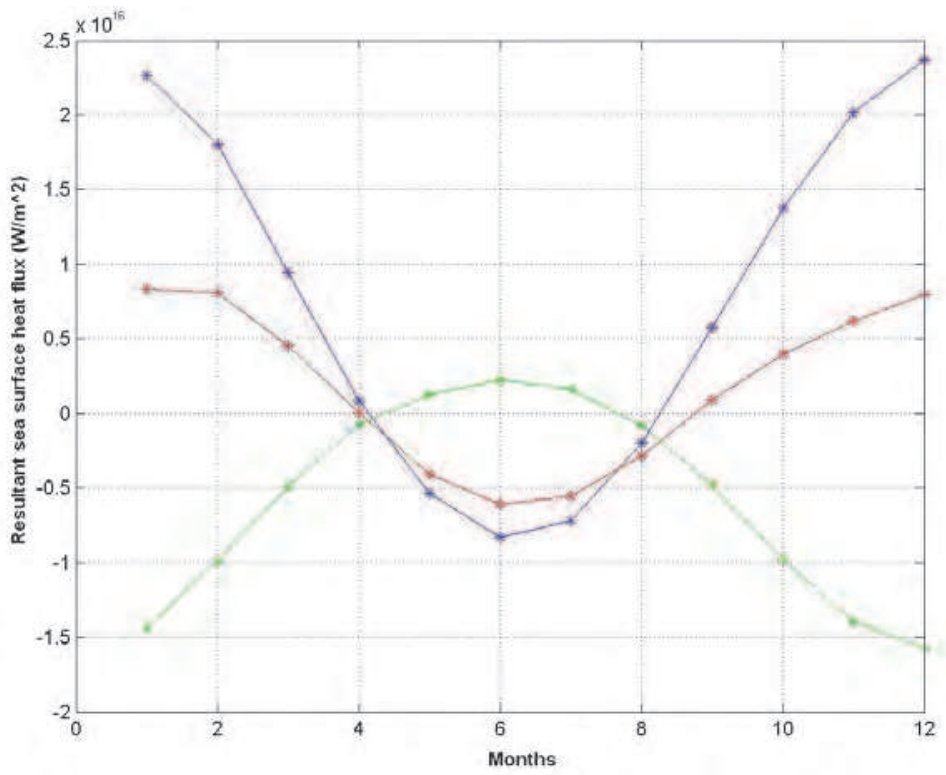

Fig. 19. Control experiment monthly mean resultant sea surface heat flux (W/m2) time series plot. Blue line represents southern hemisphere ocean resultant surface heat flux; green line represents the same property for the northern hemisphere while the red line represents the global resultant surface heat flux.

were not considered in the perturbed experiment. This experiment maintained the climatological radiation fields used in the control experiment. Figure 19 shows the control experiment resultant sea surface heat fluxes for the northern hemisphere, the southern hemisphere and the world ocean areas. This figure reveals the dominance of the southern ocean as a great heat reservoir of the climate system, whereas the northern ocean tends to lose heat to other global reservoirs, such as the atmosphere.

Evidently the sea surface radiation balance varies in function of the ocean atmosphere interaction processes. Not consider this variability constitutes a limitation in the perturbed experiment. For the studied period (three years) these variations would represent little impact over heat and volume ocean transports but this point would be only possible to be verified by the use of an ocean-atmosphere coupled models. These models permit to quantify the amount of heat energy that is exchanged between these two climate components.

Other important point to be mentioned is related with the low meridional and zonal resolution of the model integration grid. This fact avoids the model to represent ocean 
transports, especially those related with near coast ocean features that must have significant influence in heat and volume transport estimates.

\section{Conclusions}

This work emphasised the influence of the wind stress field as an important source of ocean climate variability. Although the perturbed experiment used only a three-year duration boundary field, important changes in the global ocean kinetic energy, volume and heat transports due to an ENSO-type global wind stress field were observed. An interval of five months was observed between the SST anomaly peak and the global wind stress energy peak, and an interval of two months was observed between the latter peak and kinetic energy one.

Changes in ocean volume transport were observed not only in the upper ocean layers, which are directly influenced by wind, but also in the deep and bottom density layers. The most significant changes were observed during the second integration year of the perturbed experiment, when the global wind stress energy and, consequently, the ocean kinetic energy exhibited their highest values, respectively 145 PW and 269 PW. A decrease was observed in the upper and deep eastward volume transports associated with the ACC system during the whole perturbed experiment. This result may be related to the weakening of the eastward low level winds that flow around the Antarctic continent. Significant changes in the upper layer meridional Atlantic and Pacific volume transports were also observed. During the second integration year, it was possible to observe an intensification of the northward upper layer volume transport in the $25^{\circ}$ North Atlantic and $25^{\circ}$ North Pacific sections, in relation to the apparent increase of the low level subtropical atmospheric gyre circulation. These volume transport changes led to global ocean heat transport changes that could significantly affect the global meridional overturning cell circulation.

The meridional overturning cell changed during the whole perturbed experiment. In the second perturbed integration year, an increase of approximately $0.4 \mathrm{PW}$ of the northward heat transport at $20^{\circ} \mathrm{N}$ and of the same order to the south at $10^{\circ} \mathrm{S}$ was observed. Even though the second integration year was the most energetic, it was in the third simulated year that the highest meridional heat transport value was found, when a northward transport of 2.4 PW was observed between the equator and $20^{\circ} \mathrm{N}$. These results indicate the occurrence of interannual thermohaline circulation variability despite the short length of the perturbed experiment.

The observed changes in global ocean volume and heat transports could represent an important source of variability to the Earth's climate system and also could contribute in the knowledge of ocean's role in future climate simulations scenarios.

For future works, the use of an ENSO-type transient sea surface radiance balance forcing is recommended with the application of a coupled climate general circulation model with a higher space resolution ocean model. Another important contribution would be the use of wind stress fields from other ENSO events for replicate perturbation experiments.

\section{References}

Assad, L.P.F.; Torres Jr., A.R.; Candella, R.N.; Mascarenhas Junior, A. S. Brazil Malvinas Confluence Upper Ocean Temperature Anomalies induced by an ENSO wind forcing. Ciencias Marinas, v. 36, p. 267-284, 2010. 
Assad LPF, Torres Jr. AR, Zumpichiatti WA, Mascarenhas Jr. AS, Landau L. 2009. Volume and heat Transports in The World Oceans from an Ocean General Circulation Model. Braz. J. Geophys. 27(2): 181-194.

Colberg F, Reason CJC, Rodgers K. 2004: South Atlantic response to El Niño-Southern Oscillation induced climate variability in an OGCM. J. Geophys. Res. 109: C12015, doi:10.1029/2004JC002301.

Ganachaud, A. \& C. Wunsch.-2000- Improved estimates of global circulation, heat transport and mixing from hydrographic data. Nature vol: 408: 453 - 457.

Hastenrath, S., 1979. Heat Budget of Tropical Ocean an Atmosphere. Journal of Physical oceanography, 10:159-170.

Lenn, Y-D, Chereskin TK, Sprintall J, Firing E. 2007. Mean jets, mesoscale variability and eddy momentum fluxes in the surface layer of the Antarctic Circumpolar Current in Drake Passage. J. Mar.Res. 65: 27-58.

Lentini CAD, Podestá GG, Campos EJD, Olson DB. 2001. Sea surface temperature anomalies on the western South Atlantic from 1982 to 1994. Cont. Shelf Res. 21:89-112.

Murray, R.J.. 1996. Explicit generation of orthogonal grids for ocean models. Journal of Computational Physics, 126: 251-273.

Oort, A. H., L. A. Anderson AND J. P. PEIXOTO -1994 - Estimates of the energy cycle of the oceans. Journal of Geophysical Research, 99, 7665-7688.

Pacanowsky, R.C. \& S.M.Griffies.1999. The MOM3 Manual. Geophysical Fluid Dynamics laboratory/NOAA, Princeton, USA, p. 680.

Rintoul, S.R. 1991. South Atlantic Interbasin Exchange. Journal of Geophysical research, 96, 2675-2692.

Röeske, F. 2001. An Atlas of Surface Fluxes based on the ECMWF Re-Analysis - a Climatological Dataset to force Global Ocean General Circulation Models. Max Planck Institut für Meteorologie, Hamburg. Report no. 323. ISSN 0937-1060.

Russel,J.L. The Southern Hemisphere Westerlies in a Warming World: Propping Open the Door to the Deep Ocean Journal of Climate. Vol.19. 2006.

Schmitz, W.J.-1996- On The World Ocean Circulation: Volume II. Technical Report. Woods Hole Oceanographic Institution WHOI-96-08.

Stammer, D., C. Wunsch, R.Giering, C. Eckert, P. Heimbach, J.Marotzke, A. Adcroft, C.N.Hill e J.Marshall, 2003. Volume, heat, and freshwater transports of the global ocean circulation 1993-2000, etsimated from a general circulation model constrained by World Ocean circulation Experiment (WOCE) data. Journal of Geophysical Research vol. 108, pp- 7-1 - 7-23.

Sun, C., M. M. Rieneker, A. Rosati, M. Harrison,; A. Wittenberg, C. L. KeppenneEPPENNE, J. P. Jacob, AND R. M. Kovach. 2007. Comparison and sensitivity of ODASI ocean Analyses in the tropical Pacific. Monthly Weather Review, 135: 2242 2264.

Torres Jr AR. 2005. Evidências de tele-conexão atmosférica entre fenômenos oceânicos do Pacífico Equatorial e do Atlântico Sul. Tese de Doutorado, Universidade Federal do Rio de Janeiro, Rio de Janeiro, 156 pp.

Wunsch, W. 1998. The Work Done by the Wind on the Oceanic general Circulation. Journal of Physical Oceanography, vol 28: 2332-2340. 
Whitworth and Peterson, 1985. T. Whitworth, III and R.G. Peterson, Volume of transport of the Antarctic Circumpolar Current from bottom pressure measurements. Journal of Physical Oceanography 15 (1985), pp. 810-816 


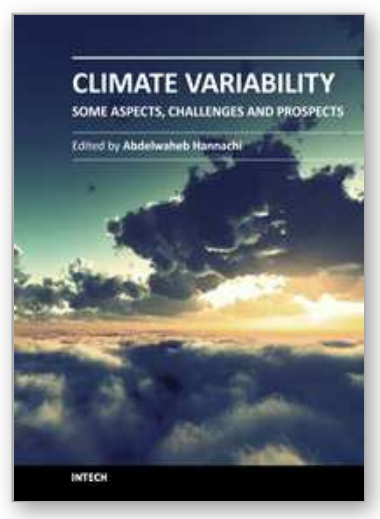

\author{
Climate Variability - Some Aspects, Challenges and Prospects \\ Edited by Dr. Abdel Hannachi
}

ISBN 978-953-307-699-7

Hard cover, 192 pages

Publisher InTech

Published online 18, January, 2012

Published in print edition January, 2012

This book provides a general introduction to the popular topic of climate variability. It explores various aspects of climate variability and change from different perspectives, ranging from the basic nature of low-frequency atmospheric variability to the adaptation to climate variability and change. This easy and accessible book can be used by professionals and non professionals alike.

\title{
How to reference
}

In order to correctly reference this scholarly work, feel free to copy and paste the following:

Luiz Paulo de Freitas Assad (2012). ENSO-Type Wind Stress Field Influence over Global Ocean Volume and Heat Transports, Climate Variability - Some Aspects, Challenges and Prospects, Dr. Abdel Hannachi (Ed.), ISBN: 978-953-307-699-7, InTech, Available from: http://www.intechopen.com/books/climate-variability-someaspects-challenges-and-prospects/enso-type-wind-stress-field-influence-over-global-ocean-volume-and-heattransports

\section{INTECH}

open science | open minds

\section{InTech Europe}

University Campus STeP Ri

Slavka Krautzeka 83/A

51000 Rijeka, Croatia

Phone: +385 (51) 770447

Fax: +385 (51) 686166

www.intechopen.com

\section{InTech China}

Unit 405, Office Block, Hotel Equatorial Shanghai

No.65, Yan An Road (West), Shanghai, 200040, China

中国上海市延安西路65号上海国际贵都大饭店办公楼 405 单元

Phone: +86-21-62489820

Fax: $+86-21-62489821$ 
(C) 2012 The Author(s). Licensee IntechOpen. This is an open access article distributed under the terms of the Creative Commons Attribution 3.0 License, which permits unrestricted use, distribution, and reproduction in any medium, provided the original work is properly cited. 